\title{
Effect of maize grain treatment on ruminal fermentation and the site and extent of starch digestion in cows
}

\author{
Z. Čerešňáková1, M. Chrenková, J. Kopčeková, A. Sommer \\ and R. Žitňan
}

\author{
Research Institute of Animal Production, Institute of Animal Nutrition \\ Hlohovská 2, 94992 Nitra, Slovak Republic
}

(Received 31 March 2003; revised version 16 November 2004; accepted 31 January 2005)

\begin{abstract}
Four non lactating cows with rumen and duodenal T-cannules were used in the $2 \times 2$ Latin square experiment to study the effect of crushed or ground maize grain on ruminal fermentation and on starch outflow from the rumen, ruminal and postruminal starch digestibility. Cows were fed diets consisting of, \%: forage 70, maize grain crushed or ground 27, soyabean meal 2 and Vitamix S 1, on dry matter basis. Maize treatment did not affect ruminal fermentation. Total VFA concentration was somewhat increased when the animals were fed ground maize $(\mathrm{P}>0.1)$. Effective starch degradability was higher $(\mathrm{P}<0.01)$ for ground $(70.7 \%)$ than for crushed maize (65.1\%). Starch passage into the duodenum was higher $(\mathrm{P}<0.01)$ when crushed than ground maize was fed $(33.5$ vs $21.2 \%)$. Postruminal digestibility of starch entering the duodenum was high for both diets ( 82.2 vs $85.5 \%$; $<<0.01$ ). Apparent total GIT digestibility of starch was affected by grain processing $(\mathrm{P}<0.05)$.
\end{abstract}

KEY WORDS: maize grain, grain processing, starch, in sacco degradability, intestinal digestibility, rumen fermentation

\section{INTRODUCTION}

The chemical composition and structure of starch in the individual grain types are primary factors which affect the rate and extent of starch digestion in the rumen (French, 1973; Kotarski et al., 1992; Mills et al., 1999a). The proportion of starch escaping rumen digestion can be altered by changing the source of starch or grain processing method. Maize starch is less degradable in the rumen than wheat, barley or oats starch, up to $40 \%$ of maize starch can be found to escape ruminal fermentation (Lebzien et al., 1997; Philippeau et al., 1999a). Physical processing of grain such as grinding, increases the ruminal degradability of starch compared with dry-rolling, chopping or crushing grains (Ørskov, 1986; Nocek

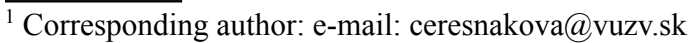


and Tamminga, 1991; Phippeau and Michalet-Doreau, 1998). Type and degree of grain processing have altered the site of starch digestion and the use of nutrients by the animal (Galyean et al., 1981).

The quantity of starch digested in the intestines has been discussed by many authors (Nocek and Tamminga, 1991; Huntington, 1997; Mills et al., 1999b; Matthé, 2001; Hindle et al., 2004; Kowalik et al., 2004). The higher resistence of starch against rumen degradation decreased starch digestion in the small intestine (Nocek and Tamminga, 1991; Mills et al., 1999b). Starch digested in the small intestine improoves the availability of the energy from the grain (Owens et al., 1986). Mills et al. (1999b) showed a mean total tract starch digestibility of $93 \%$ which was positively correlated with both ruminal and postruminal starch digestion. Type and degree of grain processing have altered the site of starch digestion and the use of nutrients by the animal (Galyean et al., 1981).

The objective of our experiment was to examine the effect of maize grain processing - crushing or grinding - on digestibility of starch in the rumen and total digestive tract, and the digestibility of starch postruminally and ruminal fermentation parameters. To complete this study, in sacco method was used to investigate the effect of processing on starch effective degradability.

\section{MATERIAL AND METHODS}

Maize grain (hybrid Svetlana) was processed in a crushing equipment Murska 350 S2 (Kemira, Finland) or in a hammer mill UH 50/18 (Germany). The samples of crushed (CM) and ground maize (GM) were separated in a set of sieves. Particles with size $>3 \mathrm{~mm}$ (78\%), with 3-1 $\mathrm{mm}(12 \%)$ and with size $<1 \mathrm{~mm}(10 \%)$ were in crushed maize. Particles with size $>2 \mathrm{~mm}(10 \%)$ with $1-2 \mathrm{~mm}(67 \%)$ and with size $<1 \mathrm{~mm}(23 \%)$ were in ground maize.

Four non lactating Holstein-Frisien cows were used in a $2 \times 2$ Latin square design experiment. The animals with a mean liveweight of $550 \mathrm{~kg}$ were fitted with large rumen fistulae and T cannulae (Bar Diamond, Inc., USA) in the proximal duodenum (about $20 \mathrm{~cm}$ distal to the pylorus). The cows were housed in tie stalls with free access to drinking water.

The cows were fed twice daily (at 6.30 and 18.30). The amount of CM and/or GM $(2.7 \mathrm{~kg} \mathrm{DM})$ in the experimental diets was set. The amounts of the other components were balanced at $1.25 \times$ maintenance ME requirements (Sommer et al., 1994) as follows, $\mathrm{kg} / \mathrm{DM}$ : maize silage 2.9 , lucerne hay 3.9, soyabean meal 0.19 , Vitamix S - Super 0.09, and fed as a mixed diets. Feed consumption was recorded daily; refusals were collected before morning feeding. The chemical composition of experimental feeds is given in Table 1. 
TABLE 1

Chemical composition of feeds, $\mathrm{g} / \mathrm{kg}$ DM

\begin{tabular}{lcccrc}
\hline $\begin{array}{l}\text { Nutrients } \\
\mathrm{n}=4\end{array}$ & $\begin{array}{c}\text { Crushed } \\
\text { maize }\end{array}$ & Ground maize & $\begin{array}{c}\text { Soyabean } \\
\text { meal }\end{array}$ & $\begin{array}{r}\text { Maize } \\
\text { silage }\end{array}$ & $\begin{array}{c}\text { Lucerne } \\
\text { hay }\end{array}$ \\
\hline DM g/kg & 857.3 & 865.7 & 893.5 & 361.7 & 888.7 \\
Crude protein & 94.8 & 97.6 & 509.3 & 78.6 & 168.8 \\
Crude fibre & 27.0 & 27.7 & 43.8 & 197.9 & 378.3 \\
Ether extract & 45.2 & 47.1 & 17.8 & 38.8 & 17.6 \\
Starch & 716.1 & 726.3 & 65.3 & 375.7 & 52.3 \\
NFE $^{1}$ & 823.1 & 823.6 & 356.1 & 640.8 & 364.2 \\
Organic matter & 984.1 & 985.7 & 927.0 & 955.8 & 928.6 \\
\hline
\end{tabular}

${ }^{1}$ nitrogen-free extractives

A 14-day adaptation period was followed by a pre-experimental period (two days) during which duodenal chymus and faeces were collected for the determination of Cr blank levels. In the following 10 days and during the sampling of duodenal digesta and faeces the animals received daily $100 \mathrm{~g} \mathrm{of} \mathrm{Cr}_{2} \mathrm{O}_{3}$, as a nutrients flow marker, in four portions $\left(25 \mathrm{~g}_{\text {of }} \mathrm{Cr}_{2} \mathrm{O}_{3}\right.$ - marker wrapped in filter paper was placed in the rumen via the rumen fistulae at 6 and, 12 a.m., 6 and 12 p.m). Preparation of $\mathrm{Cr}$ - marker was similar to those reported by Rohr et al. (1979). Cr content was $129.2 \pm 0.3 \mathrm{mg}$ in $1 \mathrm{~g}$ of $\mathrm{Cr}_{2} \mathrm{O}_{3}$ - marker.

In the sampling period (on day 1,2,4 and 5) duodenal samples were taken every $2 \mathrm{~h}$ to obtain a composite sample from 12 subsamples of a 24-h interval (Rohr et al., 1979). Faeces grab samples were collected quantitatively in the same days like duodenal digesta into a daily samples. Every total daily sample was homogenized and $4 \%$ were taken for chemical analyses of mean daily samples. The mean faeces and duodenal digesta samples were stored at $-20^{\circ} \mathrm{C}$ prior to analysis. The aliquots of the mean faeces and duodenal digesta samples were freeze-dried and used for $\mathrm{Cr}$ and nutrient determinations.

Rumen fluid was collected just before feeding $(0 \mathrm{~h})$ and 1, 3, 6 and $8 \mathrm{~h}$ after morning feeding on $\mathrm{d} 6$ and 7 of the sampling period.

Effective degradation of maize starch and degradation parameters $(a, b, c)$ were determined by in sacco method (Harazim and Pavelek, 1999). Three rumen fistulated cows (fed twice a day by experimental diet consist of $70 \%$ forage and $30 \%$ concentrate on dry matter basis) were used for $2,3,6,9,16,24$ and $48 \mathrm{~h}$ of incubation time of CM and GM samples (with a minimum of three bags per animal, incubation and feed). The parameters of starch degradation and effective degradation were calculated using the Neway progamme based on the equations described by Ørskov and McDonald (1979). In the calculation of effective starch degradation an outflow rate of $0.06 \cdot \mathrm{h}^{-1}$ was used.

Chemical composition of feeds (Table 1), refusals, duodenal and faecal freeze dried samples were determined by the Wende system analysis (STN, 1985). 
Starch was determined by the enzymatic method according to Salomonsson et al. (1984).

Ruminal fluid $\mathrm{pH}$ was measured immediately after sampling, VFA concentration was determined using gas chromatography on a $1.8 \mathrm{~m}$ column with $10 \%$ SP1200 and $1 \% \mathrm{H}_{3} \mathrm{PO}_{4}$ on Chromosorbe WAW 80/100 mesh with isocaprylic acid as an internal standard (GC Carlo Erba). Ammonia concentration was measured by the Conway method (Voigt and Steger, 1967). Concentration of $\mathrm{Cr}$ in faecal and duodenal samples was determined by AAS (Solar 9000 Unicam Cambridge, UK) according to the procedure of Williams et al. (1962).

The data of in vivo experiment were evaluated by the analysis of variance with $\mathrm{m}$ observations (in one experiment $\mathrm{m}=2$ ) by the linear model (Gill, 1978):

$$
\mathrm{y}_{\mathrm{ijkl}}=\mu+\rho_{\mathrm{i}}+\gamma_{\mathrm{j}}+\alpha_{\mathrm{k}}+(\rho \gamma)_{\mathrm{ij}}+\mathrm{e}_{\mathrm{ijk}}
$$

where $\mathrm{y}$ is the dependent variable, $\mu$ is the overall mean, $\rho_{\mathrm{i}}$ is the fixed effect of animals, $\gamma_{\mathrm{j}}$ is the fixed effect of period, $\alpha_{\mathrm{k}}$ is the fixed effect of treatment, $(\rho \gamma)_{\mathrm{ij}}$ is the fixed effect of interaction animal $\times$ period and $\mathrm{e}_{\mathrm{ijk}}$ is the random residual effects distributed $\mathrm{N}\left(0, \sigma^{2}\right)$. The significance of differences between periods or treatments were tested on the basis of significance F-test.

The effective degradability of starch in $\mathrm{CM}$ or GM and the parameters of degradation $(a, b, c)$ were evaluated by using t-test.

\section{RESULTS}

In sacco starch degradation

Crushing compared with grinding decreased the effective degradation (edg) of maize starch by $5-6 \%$ units (Table 2). Soluble fraction a in GM was higher than in $\mathrm{CM}$ whereas that of the insoluble but degradable fraction $\mathrm{b}$ was lower $(\mathrm{P}<0.01)$. There were no differences between CM and GM in the degradation rate of fraction $b$.

TABLE 2

Characteristics of maize grain starch degradation in the rumen

\begin{tabular}{lcc}
\hline Indices & Crushed maize & Ground maize \\
\hline a, $\%$ & $29.9^{\mathrm{a}}$ & $39.1^{\mathrm{b}}$ \\
$\mathrm{b}, \%$ & $70.1^{\mathrm{a}}$ & $60.9^{\mathrm{b}}$ \\
c, \% & 0.060 & 0.062 \\
Effective degradability, $\%^{1}$ & $65.1^{\mathrm{a}}$ & $70.7^{\mathrm{b}}$ \\
\hline
\end{tabular}

means within a row with different letters significantly differ $(\mathrm{P}<0.01)$

${ }^{1}$ at $\mathrm{k}=0.06 \cdot \mathrm{h}^{-1}$ 


\section{Composition of the diets and nutrient intake}

Intake of nutrients was not influenced by the physical treatment of maize although the animals consumed slighly more the GM diet which resulted in the higher consumption of starch (Table 3 ).

TABLE 3

Mean daily intake of nutrients, $\mathrm{g}$

\begin{tabular}{lcc}
\hline \multirow{2}{*}{ Nutrients } & \multicolumn{2}{c}{ Diets } \\
\cline { 2 - 3 } & $\mathrm{CM}^{1}$ & $\mathrm{GM}^{2}$ \\
\hline Dry matter & $9353 \pm 339$ & $9636 \pm 105$ \\
Organic matter & $8818 \pm 314$ & $9118 \pm 56$ \\
Crude protein & $1178 \pm 40$ & $1187 \pm 36$ \\
Crude fibre & $2077 \pm 115$ & $2100 \pm 53$ \\
Ether extract & $297 \pm 17$ & $313 \pm 17$ \\
Starch & $2917 \pm 99$ & $3250 \pm 129$ \\
N-free extractives & $5239 \pm 194$ & $5481 \pm 34$ \\
\hline
\end{tabular}

${ }^{1}$ crushed maize diet, ${ }^{2}$ ground maize diet

\section{Rumen fermentation}

The characteristics of rumen fermentation are given in Table 4. Processing of maize did not cause any pronounced changes in rumen fermentation parameters. The changes of $\mathrm{pH}$ between 0 to $8 \mathrm{~h}$ after feeding are given in Figure 1. No effects of maize particle size upon $\mathrm{pH}$ values could be noted.

The differences in the mean molar proportion of VFA between CM and GM diets were no significant ( $\mathrm{P}>0.05$; Table 4). The changes in acetic and propionic acid concentration are illustrated in Figures $2 \mathrm{a}$ and $2 \mathrm{~b}$ throughout the observation period where the maximum for CM and GM occurred at different times after feeding. An increasing tendency of concentration of butyric acid was recorded with GM diet in comparison with $\mathrm{CM}$ diet (Figure 2c). Lactic acid

TABLE 4

Effect of crushed or ground maize grain on rumen fermentation products

\begin{tabular}{lccc}
\hline \multirow{2}{*}{ Indices } & \multicolumn{2}{c}{ Diets } & $\begin{array}{c}\text { Significance of } \\
\text { differences }\end{array}$ \\
\cline { 2 - 3 } & $\mathrm{CM}$ & $\mathrm{GM}$ & n.s. \\
Total VFA, mmol/L & $78 \pm 1.90$ & $75 \pm 1.76$ & n.s. \\
Acetic acid & $65.8 \pm 2.22$ & $65.4 \pm 2.62$ & n.s. \\
Propionic acid & $17.8 \pm 1.84$ & $17.8 \pm 1.61$ & n.s. \\
Butyric acid & $11.6 \pm 0.81$ & $11.0 \pm 1.72$ & n.s. \\
Acetate:propionate ratio & 3.69 & 3.65 & n.s. \\
pH & $6.7 \pm 0.34$ & $6.7 \pm 0.34$ & n.s. \\
Ammonia N, mmol/L & $8.29 \pm 4.02$ & $8.25 \pm 4.33$ & \\
\hline
\end{tabular}

${ }^{1}$ the data represent the mean values of five sampling time; n.s. $(\mathrm{P}>0.05)$ 


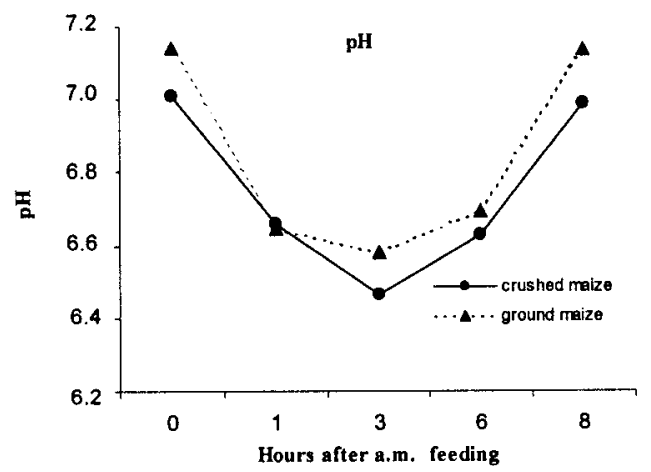

Figure 1. Rumen fluid $\mathrm{pH}$ when feeding diets containing crushed or ground maize
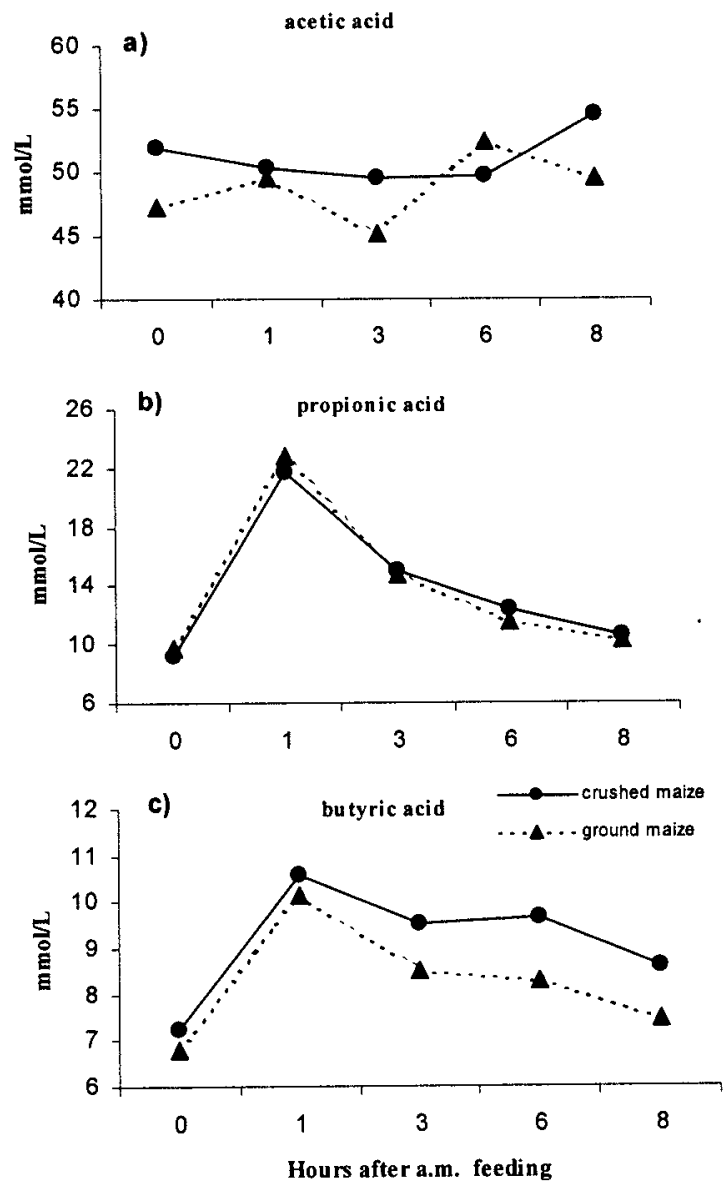

Figure 2. Changes of acetic (a), propionic (b) and butyric (c) acid concentration in the rumen fluid when feeding diets containing crushed or ground maize 
concentration was slightly increased only $1 \mathrm{~h}$ after feeding (Figure 3 ). Total VFA concentration tended to be higher in cows fed CM, however differences between $\mathrm{CM}$ and $\mathrm{GM}$ were non significant $(\mathrm{P}>0.05)$. One $\mathrm{h}$ after feeding expressive increasing in molar percentage of propionic acid in the rumen fluid resulted in decreasing of acetate:propionate ratio (Figure 4). The latter was seen to increase up to the value of 5.14 and 4.84 ( $8 \mathrm{~h}$ after feeding CM and GM, respectively). Maize grain processing did not effect concentrations of ruminal ammonia in ruminal fluid (Figure 5).

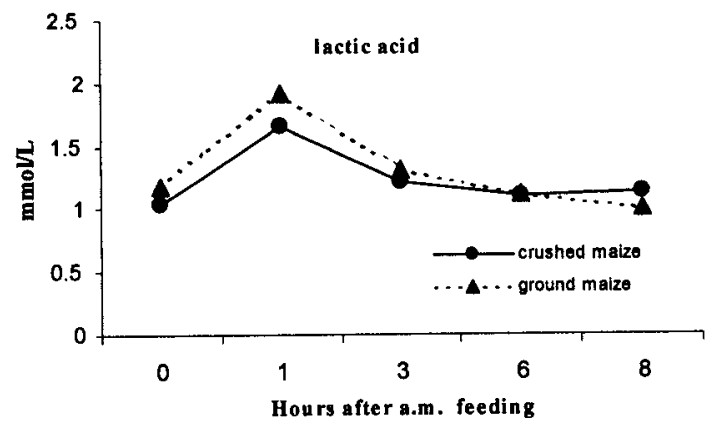

Figure 3. Changes in lactic acid concentration in the rumen fluid when feeding diets containing crushed or ground maize

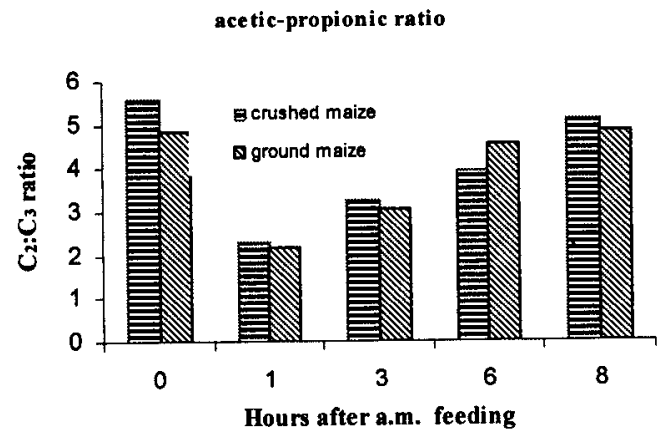

Figure 4. Changes in the acetate-to-propionate ratio in the rumen fluid after the morning feeding

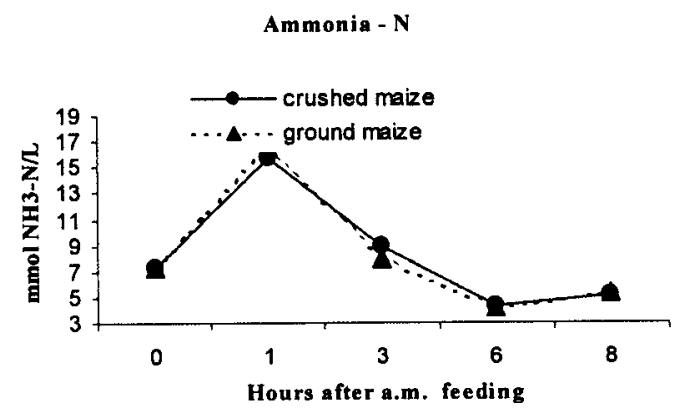

Figure 5. Changes in the ammonia $\mathrm{N}$ concetration in the rumen fluid when feeding diets containing crushed or ground maize 


\section{Ruminal and postruminal nutrient digstibility}

Neither flow to the duodenum nor postruminal DM and OM digestion were influenced significantly by maize treatment (Table 5). Of the DM passing to the duodenum were digested in the intestine, with total tract digestion that was more than $70 \%$. Rumen digestion of organic matter was similar to that of dry matter with non significant differences between $\mathrm{CM}$ and $\mathrm{GM}$ diets $(\mathrm{P}>0.05)$. Almost identical amounts of organic matter from the CM and GM diets were digested postruminally.

TABLE 5

Passage of DM and OM and their apparent digestion in various sites of the digestive tract of cows

\begin{tabular}{lccc}
\hline Parameter & \multicolumn{2}{c}{ Diets } & $\begin{array}{c}\text { Significance of } \\
\text { differences }\end{array}$ \\
\cline { 2 - 3 } $\begin{array}{l}\text { Dry matter } \\
\text { intake g/day }\end{array}$ & 9353 & 9636 & n.s. \\
passage to duodenum, g/24 h & 6340 & 6379 & \\
\% of intake & 67.7 & 66.2 & n.s. \\
$\quad$ digested in rumen \% of intake & 32.3 & 33.8 & n.s. \\
digested postruminaly, g/24 h & 3786 & 3715 & \\
\% of passage to duodenum & 59.4 & 58.0 & n.s. \\
total GIT apparent digestibility, \% & 72.6 & 72.3 & n.s. \\
Organic matter & & & \\
intake g/day & 8818 & 9118 & n.s. \\
passage to duodenum, g/24 h & 5239 & 5192 & \\
\% of intake & 59.3 & 56.9 & n.s. \\
digested in rumen \% of intake & 40.7 & 43.1 & n.s. \\
digested postruminaly, g/24 h & 2980 & 2830 & \\
\% of passage to duodenum & 56.5 & 54.1 & n.s. \\
total GIT apparent digestibility, \% & 74.3 & 74.1 & n.s. \\
\hline
\end{tabular}

n.s. at $\mathrm{P}>0.05$

Starch intake, ruminal and post-ruminal digestion are shown in Table 6 . Passage of starch of $\mathrm{CM}$ diet starch to the duodenum was significantly higher than with the GM diet $(\mathrm{P}<0.01)$. With the GM diet, as much as $78.8 \%$ of the ingested amount of starch were degraded in the rumen. With the CM diet of the ingested amount of starch as much as $33.5 \%$ passed to the duodenum and $82.2 \%$ was digested postruminally. The postruminal digestion of starch from GM diet was a slightly higher. Total apparent GIT digestion of starch was high with the significant difference between the $\mathrm{CM}$ and the GM $\operatorname{diet}(\mathrm{P}<0.05)$. 
TABLE 6

Passage and apparent digestibility of starch in various sites of the digestive tract of cows

\begin{tabular}{lccc}
\hline \multirow{2}{*}{ Starch } & \multicolumn{2}{c}{ Diet } & $\begin{array}{c}\text { Significance of } \\
\text { differences }\end{array}$ \\
\cline { 2 - 3 } Intake, g/day & CM & GM & n.s. \\
Passage to duodenum, g/24 h & 2917 & 3250 & \\
\% of intake & 970 & 686 & $* *$ \\
Digested in the rumen, \% of intake & 33.5 & 21.1 & $* *$ \\
Digested postruminaly, g/24 h & 66.5 & 78.8 & \\
\% of passage to the duodenum & 798 & 582 & n.s. \\
Total GIT apparent digestibility, \% & 82.2 & 84.8 & $*$ \\
\hline
\end{tabular}

*P $<0.05 ; * * \mathrm{P}<0.01 ;$ n.s. at $\mathrm{P}>0.05$

\section{DISCUSSION}

When animals are fed high doses of grain (wheat, barley), rapid degradation and fermentation of starch and thus an abrupt increase in VFA levels and decrease in pH occur which cause serious disturbances (De Visser and De Groot, 1981). For this reason increased attention has been paid to the use of maize or maize starch, the ruminal degradation of which is slower than that of other cereal starch (Żebrowska et al., 1997; Philippeau et al., 1999b). This phenomenon is a consequence of the different physical and chemical structure as well as the properties of proteins that encoat maize starch particles (Kotarski et al., 1992; McAllister et al., 1993).

The chemical composition and structure of starch in maize grain primary affect the rate and extent of starch in sacco disappearance and effective degradability; they are lower than for other grain species (Tamminga et al., 1990). Particles size in ground maize enhanced the soluble fraction, the rate of degradation and also effective degradation of starch. By Galyean et al. (1981) maize particles size had little effect on starch disappearance in 6,000 3,000 and 1,500 $\mu \mathrm{m}$ size (average of $9.2 \%$ ), but starch disappearance of $750 \mu \mathrm{m}$ maize was higher $(21.7 \%)$ than for other fractions. The processing method that producing smaller particles effects on the disruption of the protein matrix of the endosperm and permits easier access of bacterial or animal enzymes to the starch granules (Hale, 1973). In the present experiment larger particles in crushed maize ( $78 \%$ of size $>3 \mathrm{~mm}$ and $12 \%$ with 3-1 $\mathrm{mm}$ ) decreased the surface area, starch in sacco disappearance and effective degradability in comparison with ground maize, where $23 \%$ particles were smaller than $1 \mathrm{~mm}$ and a size of $67 \%$ of particles was $1-2 \mathrm{~mm}$.

Forages presented $70 \%$ and maize grains $27 \%$ of the dry matter of the diets with the daily intake of starch making up $31.2 \%$ and only slightly but not 
significantly higher, $33.7 \%$ of the DM of the respective rations. Loose et al. (1998) reported that the proportion of maize grain higher than $50 \%$ in diet did not cause any negative effects on the cows.

Processing of maize grains did not cause any pronounced changes in the parameters of ruminal fermentation. With both diets the mean $\mathrm{pH}$ values were 6.7 and revealed an identical course throughout the experimental period (Figure 1).

Ammonia and VFA concentrations in the rumen fluid were similar for both ground or crushed maize treatments. The similar results were found by Knowlton et al. (1998) with dry ground and rolled maize when mean partical size was 618 $\mu \mathrm{m}$ and/or $1725 \mu \mathrm{m}$. On the other hand in vitro VFA production (Belyea et al., 1997) at $24 \mathrm{~h}$ was greater for maize with the $1 \mathrm{~mm}(97 \mathrm{mmol} / \mathrm{L})$ than $5 \mathrm{~mm}$ particle size $(89 \mathrm{mmol} / \mathrm{L})$. In maize-fed animals the levels of acetic acid which is the main fermentation product of bacteria digesting cellulose and hemicelluloses increased as late as 6 and $8 \mathrm{~h}$ after feeding, respectively (Figure 2a). Propionic acid which is produced by starch-fermenting bacteria (Ørskov, 1986) and lactic acid reached maximum concentrations in $1 \mathrm{~h}$ after feeding (Figures $2 \mathrm{~b}$ and 3). The abrupt increase in propionic and lactic acid levels shortly after feeding rations containing high level of starch is often reported as a cause of digestive malfunctions, decreased production and health problems (De Visser and De Groot, 1981; Sutton et al., 1987). A marked increase of propionic acid concentration evidently decreased the acetate:propionate ratio one $h$ after feeding (Figure 4).

Nocek and Tamminga (1991) reported that a site of starch digestion and digestion within site could be manipulated as processing and feeding management strategies largely influence site digestion. Feeding larger particle size of maize to cattle reduced digestibility (Waldo, 1973). Maximum maize digestibility by cattle occureed with a modulus of fineness between 3.0 and $4.8 \mathrm{~mm}$ (Adeeb et al., 1971). In our experiment, ground maize significantly increased (66.5 vs $78.8 \%$; $\mathrm{P}<0.05$ ) in vivo ruminal starch digestion compared with crushed maize (Table 6). Similar digestibility of ground maize in the rumen was found by Waldo (1973). Feeding of finely ground maize increased rumen starch digestibility, compared with coarsely cracked maize.

The proportion of digested starch entering the small intestine depends on enzymatic activity, starch source, passage rate and particle size of the digesta (Mills et al., 1999b). The capacity for the enzymatic hydrolysis of starch entering the small intestine is important when high starch intake leads to significant quantities of starch escaping fermentation in the rumen (Mills et al., 1999b). With the CM diet $970 \mathrm{~g}$ starch passed to the duodenum within $24 \mathrm{~h}$ which was by 284 $\mathrm{g}$ more than with the GM diet. Of these amounts as much as 798 and $582 \mathrm{~g} / 24$ $\mathrm{h}$, respectively, were digested postruminally. Postruminal digestion of starch was high in both cases (over 80\%), and the difference between CM and GM diets was 
significant $(\mathrm{P}<0.01)$. There was a tendency of higher digestibility for GM diet in the intestines, where more smaler particles with larger surface area were present. The smaller maize particles are more susceptible to enzymatically digestion in the small intestine. Adequate access of enzymes to starch granules is one of the factors limiting intestinal starch digestion (Owens et al., 1986).

The grinding of maize decreased faecal starch flow and increased starch digestion in the total digestive tract because of increased starch disapearance from the large intestine (Knowlton et al., 1998). They reported starch digestion in the total tract $88.9 \%$ for dry ground maize and $98.2 \%$ for high moisture maize. Mills et al. (1999b) showed a mean total tract starch digestibility of $93 \%$ and Waldo (1973) higher, more than $99 \%$ for ground maize. In our experiment the total tract digestbility of starch from $\mathrm{CM}$ diet was significantly lower $(\mathrm{P}<0.05)$ than from GM diet (Table 6). However, the differences in total digestion were rather low (3.4\%) with GM revealing a tendency to higher digestibility.

Concluding it can be stated that maize grain processing influences the sites of starch digestion. Larger particles in crushe maize caused the lower ruminal starch degradability and increased passage of starch to the duodenum than ground maize. The crushing process decrease postruminal and total tract starch digestion. Neither crushing nor grinding affect ruminal VFA, and ammonia concetration or ruminal $\mathrm{pH}$.

\section{REFERENCES}

Adeeb N.N., Wilson G.F., Camling R.C., 1971. Physical form of maize and its digestibility in cattle and sheep. Anim. Prod. 13, 391-398

Belyea R., Soliman M., Orma A., 1997. Effects of particle size of corn and oats on digestibility and microbial protein synthesis. J. Dairy Sci. 80, Suppl. 1, P96

De Visser H., De Groot A.A.M., 1981. The influence of the starch and sugar content of concentrates on feed intake, rumen fluid, production and composition of milk. In: Proceedings of $4^{\text {th }}$ International Conference on Production Diseases in Farm Animals. München (Germany), pp. 41-48

French D., 1973. Chemical and physical properties of starch. J. Anim. Sci. 37, 1048-1061

Galyean M.L., Wagner D.G., Owens F.N., 1981. Dry matter and starch disappearance of corn and sorghum as influenced by particle size and processing. J. Dairy Sci. 64, 1804-1812

Gill J.L., 1978. Experiments and Analysis of Experiment in the Animal and Medical Science. Ames, Iowa, Iowa State University Press

Hale W.H., 1973. Influence of processing on the utilization of grains (starch) by ruminants. J. Anim. Sci. 37, 1075-1080

Harazim J., Pavelek P., 1999. Determination of crude protein and amino acids degradability by method in sacco in the rumen (in Slovak). In: Zborník z Medzinárodného Odborného Seminára „Stanovení využitelnosti živin u př̌žvýkavců. Opava, pp. 41-46

Hindle V.A., van Vuuren A.M., Klop A., Mathijssen-Kamman A.A., van Gelder A.H. Cone J.W., 2004. Site and extent of starch degradation in the dairy cow. A comparison between in vivo, in situ, and in vitro measurements, Report 04/0001176 Nutrition and Food, Wageningen UR (The Netherlands), pp. 32 
Huntington G.B., 1997. Starch utilization by ruminants: From basics to the bunk. J. Anim. Sci. 75, $852-867$

Knowlton K.F., Glenn B.P., Erdman R.A., 1998. Performance, ruminal fermentation, and site of starch digestion in early lactation cows fed corn grain harvested and processed differently. J. Dairy Sci. 81, 1972-1984

Kotarski S.F., Waniska R.D., Thurn K.K., 1992. Starch hydrolysis by the ruminal microflora. J. Nutr. $122,178-190$

Kowalik B., Kowalczyk J., Pająk J.J., Żebrowska T., 2004. Digestion of starch and crude fibre in segments of the digestive tract of sheep fed different types and amounts of starch. J. Anim. Feed Sci. 13, Suppl. 1, 123-126

Lebzien P., Shoo J., Mancini V., Jochmann K., Flachowsky G., 1997. Vergleich der in situ Abbaubarkeit verschiedener Sorten von Körnermais. Proc. Soc. Nutr. Physiol. 6, 104

Loose K., Lebzien P., Flachowski G., 1998. Vergleichende Untersuchungen zum Einfluss von Weizen- und Maisschrot auf die Umsetzungen im Verdauungstrakt von Milchkühen, 110. VDLUFA-Kongress in Giessen, VDLUFA - Verlag Darmstadt, VDLUFA - Schriftenreihe 49, 409-412

Matthé A., 2001. Nährstoffumsetzungen im Verdauungstrakt des Rindes nach Einsatz unterschiedlicher Mengen an Mais- oder Weizenstärke. Inaugural - PhD. Dissertation, Braunschweig, pp. 175

McAllister T.A., Phillippe R.C., Rode L.M., Cheng K.-J., 1993. Effect of the protein matrix on the digestion of cereal grains by ruminal microorganisms. J. Anim. Sci. 71, 205-212

Mills J.A.N., France J., Dijkstra J., 1999a. A review of starch digestion in the lactating dairy cow and proposals for a mechanistic model: 1 . Dietary starch characterisation and ruminal starch digestion. J. Anim. Feed Sci. 8, 291-340

Mills J.A.N., France J., Dijkstra J., 1999b. A review of starch digestion in the lactating dairy cow and proposals for a mechanistic model: 2. Postruminal starch digestion and small intestinal glucose absorption. J. Anim. Feed Sci. 8, 451-481

Nocek J.E., Tamminga S., 1991. Site of digestion of starch in the gastrointestinal tract of dairy cows and its effects on milk yield and composition. J. Dairy Sci. 74, 3598-3629

Ørskov E.R., McDonald I., 1979. The estimation of protein degradability in the rumen from incubation measurements weighted according to rate of passage. J. Agr. Sci. 92, 499-503

Ørskov E.R., 1986. Starch digestion in ruminants. J. Anim. Sci. 63, 1624-1633

Owens F.N., Zinn R.A., Kim J.K., 1986. Limits to starch digestion in the ruminants small intestine. J. Anim. Sci. 63, 1634-1648

Philippeau C., Michalet-Doreau B., 1998. Influence of genotype and ensiling of grain on in situ degradation of starch in the rumen. J. Dairy Sci. 81, 2178-2184

Philippeau C., Martin C., Michalet-Doreau B., 1999a. Influence of grain source on ruminal characteristics and rate, site, and extent of digestion in beef steers. J. Anim. Sci. 77, 1587-1596

Philippeau C., Le Deschault de Monredon F., Michalet-Doreau B., 1999b. Relationship between ruminal starch degradation and the physical characteristics of corn grain. J. Anim. Sci. 77, 238-243

Rohr K., Brandt M., Castrillo O., Lebzien P., Assmus G., 1979. Der Einfluss eines teilweisen Ersatzes von Futterprotein durch Harnstoff auf den Stickstoff und Aminosäurenfluss am Duodenum. Landbauforsch. Völkenrode 29, 32-40

Salomonsson A.C., Theander O., Westerlund O., 1984. Chemical characterisation of some Swedish cereal whole meal and brain fractions. Swed. J. Agr. Res. 14, 111-117

Sommer A., Frydrych Z., Vencl B., 1994. The Nutrient Requirements and Nutrient Value of Feeds for Cattle, Sheeps and Goats. $1^{\text {th }}$ revised Edition. RIAP, Nitra (Slovak Republic) 
STN, 1985. Slovak Technical Norms. Testing methods for feeding-stuffs 46 7092, Common Regulations. Bratislava

Sutton J.D., Bines J.A., Morant S.V., Napper D.L., Givens D.I., 1987. A comparison of starchy and fibrous concentrates for milk production, energy utilization and hay intake by Friesian cows. J. Agr. Sci. 109, 375-386

Tamminga S., Van Vuuren A.M., Van der Koolen C.J., Ketelaar R.S., Van der Togt P.L., 1990. Ruminal behaviour of structural carbohydrates, non structural carbohydrates and crude protein from concentrate ingredients in dairy cows. Neth. J. Agr. Sci. 38, 513-526

Voigt J., Steeger H., 1967. Zur quantitativen Bestimmung von Ammoniak, Harnstoff und Ketokörpern in biologischem Material mit Hilfe eines modifizierten Mikrodiffusionsgefässes. Arch. Tierernähr. 17, 289-293

Waldo D.R., 1973. Extent and partition of cereal grain starch digestion in ruminants. J. Anim. Sci. 37, 1062-1074

Williams C.H., David D.J., Jismaa O., 1962. The determination of chromic oxide in faeces samples by atomic absorption spectrophotometry. J. Agr. Sci. 59, 381-385

Żebrowska T., Długołęcka Z., Pająk J.J., Korczyński W., 1997. Rumen degradability of concentrate protein, amino acids and starch, and their digestibility in the small intestine of cows. J. Anim. Feed Sci. 6, 451-470

\section{STRESZCZENIE}

\section{Wpływ obróbki ziarna kukurydzy na przebieg fermentacji w żwaczu oraz rozmiar i miejsce trawienia skrobi przez krowy}

W doświadczeniu przeprowadzonym w układzie kwadratu łacińskiego $2 \times 2$, na 4 zasuszonych krowach z przetokami do żwacza i dwunastnicy, badano wpływ gniecenia bądź śrutowania ziarna kukurydzy na fermentację i wypływ skrobi ze żwacza oraz jej strawność w żwaczu i dalszych odcinkach przewodu pokarmowego. Krowom podawano diety złożone (\% s.m.) z paszy objętościowej, 70; ziarna kukurydzy gniecionej lub śrutowanej, 27; śruty sojowej, 2 i preparatu witaminowego S, 1. Sposób traktowania kukurydzy nie wpłynął na przebieg fermentacji w żwaczu, stężenie LKT w żwaczu było jednak nieco większe, ale nieistotnie, u zwierząt otrzymujących kukurydzę śrutowaną. Efektywny rozkład w żwaczu skrobi kukurydzy śrutowanej był większy $(\mathrm{P}<0,01)$ niż gniecionej, odpowiednio 70,7 vs $65,1 \%$; do dwunastnicy przechodziło więcej skrobi gniecionej, 33,5\% niż śrutowanej, 21,2\% $(\mathrm{P}<0,01)$. Skrobia kukurydzy śrutowanej przechodząca do dwunastnicy była trawiona $\mathrm{w}$ mniejszym stopniu $(\mathrm{P}<0.01) \mathrm{w}$ dalszym odcinku przewodu pokarmowego $(82,2 \%)$ niż kukurydzy gniecionej $(85,5 \%)$. Strawność w całym przewodzie pokarmowym skrobi śrutowanej była większa $(\mathrm{P}<0,05)$ niż gniecionej $(94,0$ vs $96.8 \%)$. 